\title{
The anatomy as a tool for the identification of the bark of Pterocarpus angolensis and Terminalia sericea ${ }^{1}$
}

\author{
Teresa Quilhó $\mathbb{0}^{2 *}$ Fernanda Bessa ${ }^{2}$ Ana Isabel Ribeiro-Barros ${ }^{3}$ Natasha Ribeiro ${ }^{4}$
}

\author{
${ }^{1}$ Selected from the IV Brazilian Congress of Wood Science and Technology \\ ${ }^{2}$ Universidade de Lisboa, Instituto Superior de Agronomia, Centro de Estudos Florestais, Tapada da Ajuda, 1349-017 Lisboa, Portugal \\ ${ }^{3}$ Universidade de Lisboa, Instituto Superior de Agronomia, Centro de Investigação em Agronomia, Alimentos, Ambiente e Paisagem, Tapada \\ da Ajuda, 1349-017 Lisboa, Portugal \\ ${ }^{4}$ Universidade Eduardo Mondlane, Faculdade de Agronomia e Engenharia Florestal, Av. Julius Nyerere, Campus 3453, Maputo, Moçambique
}

Original Article

*Corresponding author: terisantos@isa.ulisboa.pt

Keywords:

Secondary phloem

Anatomical structure

Species distinction

Medicinal plants.

Palavras-chave:

Floema secundário

Estrutura anatômica

Distinção de espécies

Plantas medicinais

Received in

2019/05/12

Accepted on

2019/11/12

Published in

2020/03/04

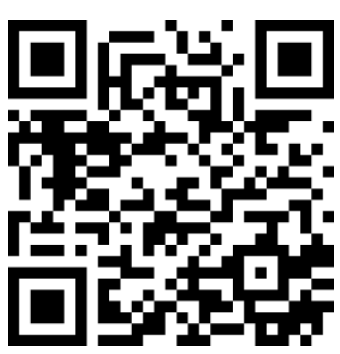

DOI:http://dx.doi.org/10.340 62/afs.v7i1.9807

\section{(cc) BY}

ABSTRACT: Pterocarpus angolensis and Terminalia sericea are two African species with medicinal potential. Despite the importance of their bark as a powerful astringent to treat various diseases it is poor described. In order to provide referential information for correct identification and standardization of the plant material, bark samples from each two species were collected and analyzed under light and electron microscopy. Some important anatomical features to identification were: the sclerenchyma tissue mostly in form of fibre-sclereids and the large secretory cells arranged in conspicuous rows or tangential bands in the conducting phloem in $P$. angolensis; the crystalliferous cells arranged in very regular tangential rows (druses) and the occurrence of large crystal cells near or including the tangential fibre bundles in T. sericea bark. The results obtained show that the anatomy of the bark can be used as an important subsidy in identification and standardization of the studied species contributing the scientific knowledge for more effective forms of scrutiny in preventing commercial adulteration of species.

\section{A anatomia como ferramenta para a identificação da casca de Pterocarpus angolensis e Terminalia sericea}

RESUMO: Pterocarpus angolensis e Terminalia sericea são espécies africanas com potencial medicinal. Apesar da importância da sua casca como um adstringente poderoso para tratar várias doenças, a sua descrição é escassa. Para a correta identificação e padronização do material vegetal, foram coletadas amostras de casca de cada espécie e analisadas ao microscópio ótico e eletrônico. Consideraram-se como características importantes para a sua identificação: o esclerênquima, maioritariamente sob a forma de fibroesclereídos em $P$. angolensis e as células secretoras de grande dimensão dispostas em linhas ou faixas tangenciais distintas logo no início do floema condutor; células cristalíferas (drusas) em linhas tangenciais regulares e ocorrência de um enorme cristal, junto ou incluso nas faixas tangenciais de fibras em $T$. sericea. Os resultados obtidos provam que a anatomia da casca pode ser utilizada como um importante subsídio na identificação e estandardização das espécies podendo o conhecimento científico contribuir para formas de fiscalização mais efetivas na prevenção da adulteração das espécies no comércio. 


\section{Introduction}

Bark has a major role as a sources of natural products used in traditional medicine. In recent years experimental studies on bark show their potential bioactivity (Carmo et al. 2016a, b. c; Miranda et al. 2016). In order to contribute to the plant identification the present study reports a brief anatomical qualitative bark description of Pterocarpus angolensis DC. and Terminalia sericea Burch. ex DC., two popular medicinal species in the miombo woodlands (Moura et al. 2017; Mongalo et al. 2016), one of the most important ecosystems in southern Africa that is increasingly threatened by climatic and anthropogenic disturbances (Ribeiro et al. 2015).

$P$. angolensis is a deciduous tree belonging to the family Fabaceae, commonly called as African bloodwood mukwa, kiaat, muninga (TakawiraNyenya 2005). In traditional medicine the bark with its blood-red, gummy, resinous exudate ('false dragon's blood' or 'kino') is used as a powerful astringent, e.g. to treat diarrhoea, heavy menstruation, nose bleeding, headache, stomachdisorders, gonorrhea, sores and skin lesions (Moura et al. 2017).

$T$. sericea is a deciduous tree belonging to the family of Combretaceae commonly called silver Terminalia (Mongalo et al. 2016); pulverized bark is applied to wounds and taken to treat diabetes, cough, sore throat and stomach-ache (Lemmens 2009). Adulteration of botanical material in commerce is common and microscopic evaluation of bark via light microscopy and scanning electron microscopy (SEM) provides referential information for correct identification and standardization of the plant material (Serrano et al. 2010).

Anatomical descriptions are the first step towards establishing the identity of raw material, but the knowledge on bark characteristics is limited to a small number of species and scarce even for those species with high wood commercial exploitation; this is the case of $P$. angolensis threatened by excessive exploitation for its valuable timber (Mogeremane 2016). There is any reference for $P$. angolensis and $T$. sericea. Recently studies on Terminalia sp. e.g. T. arjuna (Sivaji et al. 2012), T. chebula (Ingle and Dhabe 2015) and T.citrina (Ingle \& Dhabe 2011) enlightening the bark diagnostic features for standardization of the species and for detecting drug adulterations.

The objective of this study was to analyze the anatomy of bark of $P$. angolensis DC and $T$. sericea Burch. ex DC. for its correct identification. The findings from this study would be useful as standards for the species as well as a source of reference for further scientific investigation on the species enabling the diffusion of scientific knowledge to the society.

\section{Material and Methods}

The anatomical studies were conducted on the barks samples of $P$. angolensis, and $T$. sericea growing in northern Mozambique (Miombo). Bark samples were collected at Dbh $(1.30 \mathrm{~m}$ above ground) using a cutlass and then removing it from the trunk by tapping with a hammer. In the laboratory samples were impregnated with DP1500 polyethylene glycol according Barbosa et al. (2010). Transverse and longitudinal microscopic sections of approximately $17 \mu \mathrm{m}$ thicknesses were prepared with a Leica SM 2400 microtome. The sections were stained with a double staining of chrysodine/astra blue and were mounted on Kaiser glycerin. After 24 $\mathrm{h}$ drying, the lamellas were submerged into xylol for 30 minutes, dehydrated on $96 \%$ and $100 \%$ alcohol and mounted on Eukitt. Individual specimens were also taken sequentially from the cambium towards the periphery and were macerated in a 1:1 solution of $30 \% \mathrm{H}_{2} \mathrm{O}_{2}$ (hydrogen peroxide) and $\mathrm{CH}_{3} \mathrm{COOH}$ (glacial acetic acid) at $60^{\circ} \mathrm{C}$ for $48 \mathrm{~h}$ and stained with astra blue. Light microscopic observations were made using Leica DM LA and photomicrographs were taken with a Nikon Microphot-FXA. Small samples with approximately $5 \mathrm{~mm}$ of edge were cut with a sharp razor blade, and their surfaces were examined with a scanning electron microscope (SEM) Hitachi TM 3030 Plus at $5 \mathrm{kV}$ with different magnifications, and the images were recorded in digital format. The bark terminology followed Angyalossy et al. (2016).

\section{Results}

Pterocarpus angolensis DC.

Secondary phloem is non-layered and the secretory cells produce the main pattern. The secretory cells are large distributed within the entire secondary phloem arranged in conspicuous rows or tangential bands (Figure 1A, 2A-C) appearing early in the conducting phloem. The secretory cells are filled with a prominent muss of reddish content. The sieve tubes elements (conducting cells) are mostly isolated and appeared interspersed within the axial parenchyma (storage tissue) which formed bands enclosing the tangential bands of secretory cells and sclerenchyma tissue (mechanical tissue) throughout the phloem. The sclerenchyma tissue are mostly in form of sclereids and fibre-sclereids arranged in short or long tangential clusters, mixed with few fibres. The sclereids had different shape and size, round to rectangular and the fibre-sclereids had short cell body and lateral projections with blunt or pointed end walls, both with thick walls (Figure 1B- 
C). Rays are uniseriate, homogeneous with procumbent cells and stratified. Rays (storage/conducting tissue) distorted slightly near the sclerenchyma and/or the secretory cell bundles or enlarged shortly within the nonconducting phloem toward outside Crystals of calcium oxalate appeared mostly in forms of prisms occurring in series of axial parenchyma (Figure 1C).

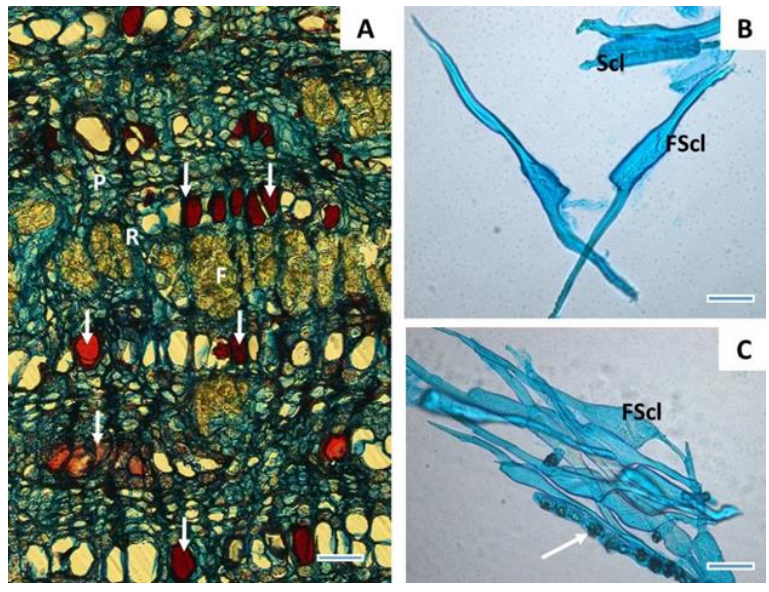

Figure 1. Secondary phloem of $P$. angolensis. A) Transverse section; B) individualized cells. Rays (R); fibers (F); axial parenchyma (P); secretory cells (arrows in A) and crystals (arrows in C); sclereids (Scl); fibre-sclereids (Fscl). Scale bar $=100 \mu \mathrm{m}$
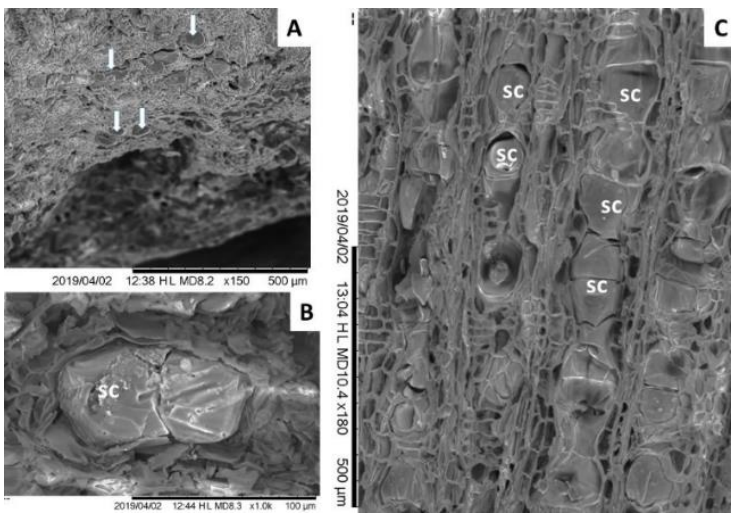

Figure 2. Secondary phloem of $P$. angolensis (SEM). A) Transverse section; secretory cells (arrows); B) large secretory cell (Sc); C) secretory cells (Sc), radial section.

\section{Terminalia sericea Burch. ex DC.}

Secondary phloem is layered and almost regular from cambium to the periphery. The conducting phloem includes layers of tangential bands of parenchyma cells and sieve tube elements alternating with groups or tangential bands of fibres. The axial parenchyma cells are arranged in various seriate tangential bands: rows of crystalliferous parenchyma cells arranged in very regular tangential rows are followed by rows of normal parenchyma cells as seen in transverse section (Figure 3A). On the transverse section the fibres are arranged regularly in short alternating plates mixed with long tangential bands somewhat undulated. The rays are non-storied, mostly uniseriate sometimes biseriate of procumbent cells; rays are thin when cross the fibres bundles but between them rays start to dilate by inflation or cell division. Sclereids and expanded axial parenchyma cells are complete absent. Inorganic inclusions: a prominent circular to oval crystal cells arise from parenchyma cells and are observed near/or including the fibre bundles (Figures 3A-C).
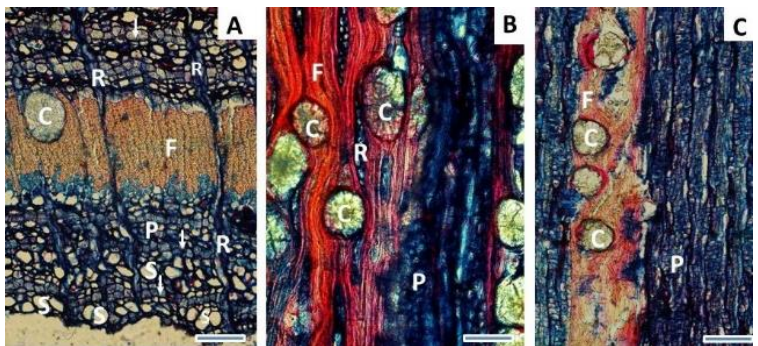

Figure 3. Secondary phloem of $\mathrm{T}$. sericea. A) Transverse section; B) tangential section; C) radial section; rays $(\mathrm{R})$; fibers $(\mathrm{F})$; axial parenchyma $(\mathrm{P})$;sieve tubes $(\mathrm{S})$; large crystal (C) and crystals in axial parenchyma (arrows). Scale bar $=100 \mu \mathrm{m}$

Also druses in chambered parenchyma cells are arranged in very regular tangential rows as seen in transverse section (Figure. 3A and Figure, 4A-C). Organic content, presumably phenolic compounds are observed in parenchyma tissue.
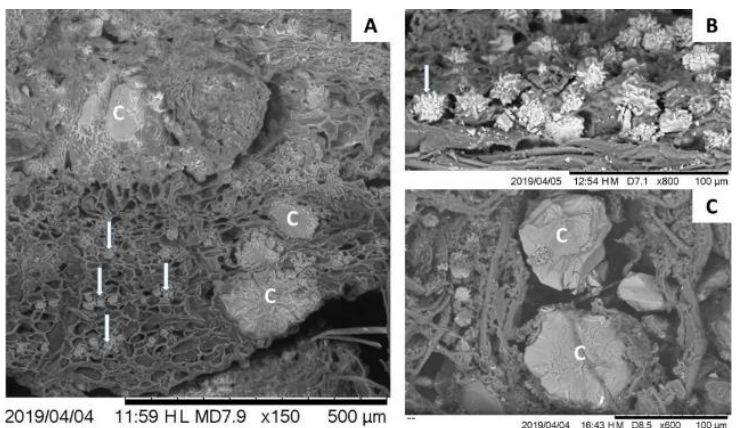

Figure 4. Secondary phloem of T. sericea (SEM). A) Crystals in parenchyma cells in tangential rows (arrows, druses), B) druses (arrows) and C) large crystals (c).

\section{Discussion}

Bark comprises all tissues outside the vascular cambium including the secondary phloem, the periderm and rhytidome (Angyalossy et al. 2016), therefor has a highly complex and heterogeneous structure. In our study only the secondary phloem was analyzed. According to our results, the general anatomy of $P$. angolensis (Figure 
1,2) and T. sericea (Figure 3, 4) bark had some similarities with other species of Pterocarpus, Terminalia and other genus of the family Fabaceae and Combretaceae detailed described by Roth (1981).

In present study the anatomical analysis of bark under light and scanning electron microscopy allowed the distinction of the two studied species by type of sclerenchyma and the secretory structures in $P$. angolensis and by crystal cells in $T$. sericea.

Sclerenchyma usually includes fibres, fibresclereids, and sclereids (Quilhó et al. 2013) but in $P$. angolensis the sclerenchyma tissue are mostly in form of sclereids and fibre-sclereids, which were mainly observed in maceration (Figure $1 \mathrm{~B}-\mathrm{C}$ ); these cells results from the modification of parenchyma cells and give mechanical support to the phloem tissue (Angyalossy et al. 2016). Also in our study particular attention was given on the development of the secretory system and the form, shape and occurrence of crystal cells in the secondary phloem, since the powdered crude drugs can be identified based on the form, the presence or absence of different cell types and cell inclusions (Alamgir 2017). In this sense recent studies were conducted with different species helpful for its discrimination ensuring safety for commercial pharmacological uses e.g. Acacia suma Roxb (Dash et al. 2014) and Erythrina $\times$ neillii Mabberley \& Lorence (Gabr et al. 2017). Secretory structures with various arrangement in phloem are often of high diagnostic value and restricted to certain families such as Sapotaceae, Moraceae, Meliaceae (Roth, 1981). Conspicuous secretory cells observed in P.angolensis were also reported in other Fabaceae e.g.in Centrolobium paraense in tangential bands or even in the form of almost continuous rings in Machaerium sp. by Roth (1981).Special attention is addressed to the arrangement of prominent circular to oval crystal cells imposing a conspicuous pattern in secondary phloem of $T$. sericea (Figure 3,4); the abundant presence of enormous crystals also stated by various authors in other Combretaceae e.g. in tangential rows, each cell containing a druse were observed in T.amazonia, T guayanensis (Roth 1981) or the development of giant crystal cells in T.arjuna (Sivaji et.al 2012).

The present study shows the significance of anatomical analysis as a tool for an accurate identification of the two species and may serve as a reference point for other new researches in order to disseminate the scientific knowledge of plants widely used in traditional medicine.

\section{Conclusions}

The anatomical structure of secondary phloem of Pterocarpus angolensis and Terminalia sericea was analyzed for the first time. The barks of the two species were markedly different and distinguished by the type of sclerenchyma and the large secretory cells arranged in conspicuous rows or tangential bands in $P$. angolensis and by the arrangement of the crystalliferous cells and occurrence of large crystal cells near or including the fibre bundles and in T. sericea.

The present study proves the significance of anatomical analysis as a tool for identification of these plants. It will be useful for the authentication of herbal products avoiding the presence of adulterants and thereby contributing to the scientific world of research.

\section{Acknowledgements}

This work was funded by the National Research Fund from Mozambique Proj 258-FN and the research units through the strategic projects UID/AGR/00239/2013/UIDB/00239/2020 (CEF) and UID/AGR/04129/2013 (LEAF) from School of Agriculture, University of Lisbon. The authors thank José C. Rodrigues and Isabel Moura for the field assistance and Cristiana Alves for the preparation of the microtome.

\section{References}

Alamgir ANM. (2017) Therapeutic use of medicinal plants and their extracts. Vol. 1 Pharmacognosys. K.D. Rainsford (Ed.), Progress in Drug Research 73, Springer International Publishing AG. 546p

Angyalossy V, Pace MR, Evert RF, Marcati CR, Oskolski AA, Terrazas T. et al. (2016) IAWA List of microscopic bark features. International Association of Wood Anatomists Journal, 37: 517- 615. doi: 10.1163/22941932-20160151

Barbosa ACF, Pace MR, Witovisk L, Angyalossy V (2010) A new method to obtain good anatomical slides of heterogenerous plant parts. International Association of Wood Anatomists Journal, 31: 373-383.

Carmo JF, Miranda I, Quilhó T, Sousa VB, Cardoso S, Carvalho AM (2016a) Chemical and structural characterization of the bark of Albizia niopoides trees from the Amazon. Wood Science Technology, 50 (4): 677-69. doi: 10.1007/s00226-016-0807-3. 
Carmo F, Miranda I, Quilhó T, Sousa VB, Cardoso S, Carvalho AM, Carmo FHDJ, Latorraca JVF, Pereira H (2016b) Copaifera langsdorffii bark as a source of chemicals: structural and chemical characterization. Journal Wood Chemistry Technology, $36 \quad$ (5):1-13. doi: 10.1080/02773813.2016.1140208.

Carmo F, Miranda I, Quilhó T, Carvalho AM, Carmo, FHDJ, Latorraca, JVF, Pereira $\mathrm{H}$ (2016c) Bark characterisation of the Brazilian hardwood Goupia glabra in terms of its valorisation. Bioresources, 11(2): 4794-4807.

doi:

10.15376/biores.11.2.4794-4807

Dash GK, Abdullah MS, Acharyya S (2014) Pharmacognostic Evaluation of the Bark of Acacia suma Roxb (Fabaceae).Journal of Pharmaceutical Research, 13 (6): 961-966. http://dx.doi.org/10.4314/tjpr.v13i6.20

Gaber SK., Bakr RO, Elshishtawyb HM, ElFishawyc AM, El-Alfy TS (2017) Botanical and genetic characters of Erythrina $\times$ neillii cultivated in Egypt. Revista Brasileira de Farmacognosia, 27:273-281. http://dx.doi.org/10.1016/j.bjp.2017.02.005

Ingle P, Dhabe A (2011) Pharmacognostic studies on Terminalia citrina (Gaertn)

Roxb. ex Fleming. Pharmacognosy

Journal, 3 (20): 63-65.

https://doi.org/10.5530/pj.2011.20.12

Ingle P, Dhabe A (2015) Anatomical investigation of Terminalia chebula Retz. Phytotaxonomy. Vol. 15: 55-62.

Lemmens R.HMJ (2009) Terminalia sericea Burch. ex DC. In: Lemmens, R.H.M.J., Louppe, D. \& Oteng-Amoako, A.A. (Editors). PROTA (Plant Resources of Tropical Africa / Ressources végétales de l'Afrique tropicale), Wageningen, Netherlands. Accessed 6 February 2020.

Miranda I, Lima L, Quilhó T, Knapic S, Pereira H (2016) The bark of Eucalyptus sideroxylon as a source of phenolic extracts with anti-oxidant properties. Industrial Crops Products, 82: 81-87. https://doi.org/10.1016/j.indcrop.2015.12.0 03

Mongalo NI, McGaw LJ, Segapelo TV, Finnie JF, Staden JVan (2016) Ethnobotany, phytochemistry, toxicology and pharmacological properties of Terminalia sericea Burch. ex DC. (Combretaceae) - A review. Journal of Ethnopharmacology, 194: 789 -802. doi: 10.1016/j.jep.2016.10.072

Mogeremane W (2016) A Review of Pterocarpus angolensis DC. (Mukwa) an Important and Threatened Timber Species of the Miombo Woodlands. Research Journal of Forestry. 10 (1):8-14. doi: 10.3923/rjf.2016.8.14

Moura I, Maquia I, Rija AA, Ribeiro N, Ribeiro-Barros AI (2017) Biodiversity studies in key species from the African Mopane and Miombo Woodlands Genetic Diversity. Lidija Bitz, IntechOpen, DOI: 10.5772/66845. Available from: https://www.intechopen.com/books/genetic -diversity/biodiversity-studies-in-keyspecies-from-the-african-mopane-and$\underline{\text { miombo-woodlands }}$

Isabel Moura, Ivete Maquia, Alfan A. Rija, Natasha Ribeiro and Ana Isabel RibeiroBarros (March 1st 2017). Biodiversity Studies in Key Species from the African Mopane and Miombo Woodlands, Genetic Diversity

Quilhó T, Sousa V, Tavares F, Pereira H (2013) Bark anatomy and cell size variation in Quercus faginea. Turkish Journal of Botany, 37:561-570 doi: 10.3906/bot1201-54

Ribeiro NS, Syampungani S, Nangoma D, Ribeiro-Barros A (2015) Miombo woodlands research towards the sustainable use of ecosystem services in southern 
Africa. In: Lo Y-H., Blanco, J.A., Roy, S. (eds), Biodiversity in ecosystems - linking structure and function, Intech, Rijeka, p493-409.

Roth I (1981). Structural patterns of tropical barks. Encyclopedia of plant anatomy Vol. LX, Part 3. Gebruder Borntraeger, Berlin,Stuttgart. 609p

Serrano R, Silva G, Silva O (2010) Application of Light and Scanning Electron Microscopy in the Identification of Herbal Medicines. In: A Méndez-Vilas, J. Díaz, editor. Microscopy: Science, Technology, Applications and Education. Badajoz Spain, p182-190

Sivaji K, Mahendra M, Ramesh L, Madhava K (2012) Comparative pharmacognostical studies of Terminalia arjuna used in ayurvedic drug "arjuna" with its adulterant Kavalama urens. Indian Journal of Plant Sciences. Vol. 1 (2\&3): 229-238. ISSN: 2319-3824 (Online)

Takawira-Nyenya, R (2005) Pterocarpus angolensis DC. In: Louppe, D., OtengAmoako, A.A. \& Brink, M. (Editors). PROTA (Plant Resources of Tropical Africa/Ressources végétales de l'Afrique tropicale), Wageningen, Netherlands. Accessed 28 January 2020 